\title{
DETERMINANTS OF EMPLOYEE PERFORMANCE IN RELIGION-BASED NGO: LESSONS FROM THE FUNDRAISING DIVISION OF THE DOMPET DHUAFA AMIL ZAKAT INSTITUTION
}

\author{
Anwar Hadi Musaddad ${ }^{* 1}$, Didin Hafidhuddin**), and Idqan Fahmi*) \\ *) School of Business, IPB University \\ Jl. Pajajaran, Bogor 16151 \\ **) Departement of Economics, Faculty of Economics and Management, IPB University \\ Jl. Agatis, Campus of IPB Darmaga Bogor 16680
}

\begin{abstract}
Working in a religion-based institution has some unique values compared to other institutions in general. These characteristics can be a distinguishing factor that influence employee performance between the two institutions that are interesting to be examined. This research focuses on analyzing the factors that influence the employee performance of Fundraising Division of the Dompet Dhuafa Amil Zakat Institution, e.g., the ability, effort, management support, internal division support, and program division support. The purposes of this research are 1) to analyze employee performance of the fundraising division; 2) to analyze factors that influence employee performance of the fundraising division and to compare the results with other institutions; and 3) to formulate the strategy to improve employee performance of the fundraising division. The data was collected using a structural questionnaire with the employee of the fundraising division as respondents. The data collected was then analyzed using descriptive analysis and Partial Least Square. The results indicate that the employee performance of the fundraising division was rated good. The effort factor, internal division support, and program division support have a significant positive effect on employee performance in the fundraising division. Leadership training, value internalization, and performance optimization are then selected as the strategies to increase employee performance of the fundraising division.
\end{abstract}

Keywords: fundraising, employee performance, dompet dhuafa, PLS SEM

\begin{abstract}
Abstrak: Bekerja di lembaga yang berbasiskan agama memiliki karakteristik berbeda dalam hal nilai dibandingkan dengan bekerja di lembaga yang tidak berbasiskan agama. Karakteristik tersebut dapat menjadi faktor pembeda yang memengaruhi kinerja karyawan di antara kedua lembaga yang menarik untuk dikaji. Penelitian ini fokus menganalisis faktor-faktor yang memengaruhi kinerja karyawan Divisi Fundraising Lembaga Amil Zakat (LAZ) Dompet Dhuafa yaitu kemampuan, upaya, dukungan manajemen, dukungan internal divisi, dan dukungan divisi program. Tujuan penelitian ini adalah menganalisis kinerja karyawan, menganalisis faktor-faktor yang memengaruhi kinerja karyawan dan membandingkan hasilnya dengan lembaga lain, serta merumuskan strategi untuk meningkatkan kinerja karyawan. Metode pengumpulan data dilakukan self administered dengan menggunakan kuesioner. Pengambilan sampel dilakukan dengan metode purposive sampling terhadap karyawan divisi fundraising. Data terkumpul kemudian diolah dengan analisis statistika deskriptif dan Partial Least Square. Hasil dari penelitian ini adalah kinerja karyawan divisi fundraising secara umum dikategorikan baik. Faktor upaya, dukungan internal divisi, dan dukungan divisi program berpengaruh signifikan positif terhadap kinerja karyawan divisi fundraising. Strategi untuk meningkatkan kinerja karyawan divisi fundraising adalah dengan membuat pelatihan kepemimpinan, menginternalisasi nilai-nilai lembaga, dan menjaga serta meningkatkan kinerja divisi Program.
\end{abstract}

Kata kunci: fundraising, kinerja karyawan, dompet dhuafa, PLS SEM

\footnotetext{
${ }^{1}$ Corresponding author:

Email: anwaruna99@gmail.com
} 


\section{INTRODUCTION}

Working in a religion-based institution is unique in terms of value because employees who work in a religionbased institution are given an afterlife motivation as they intended to help their religion. It proves that the employee performance who work in institutions can be linked to their religious motivation. However, employees who work in other institutions in general do not have religious motivation related to religion. Employees of the Fundraising Division of the Dompet Dhuafa Amil Zakat Institution (LAZ DD) is an example of a religionbased civil society organization (Non-Governmental Organization/NGO) that one of the fund sources are zakat funds. The employee performance of LAZ DD Fundraising Division can be seen through the amount of zakat funds collection, which is how large zakat funds that can be collected compared to its potential.

The potential of national zakat in 2011 reached 3.4\% of total GDP or around 217 trillion rupiah, while in 2015, according to the research of the National Amil Zakat Agency (BAZNAS) the potential of zakat reached 286 trillion rupiah. Compared to the acquisition of zakat in 2015 which was only 3.7 trillion rupiah, the acquisition of zakat only reached $1.3 \%$ of the potential zakat which should be obtained by the zakat management institution (BAZNAS, 2017). This is in line with Canggih's research (2017) which stated that the potential for realization increased along the years of 2011-2015, but the receipt of zakat was only less than $1 \%$. The amount of acquisition and potential of zakat can be seen in Table 1 .

Based on the existing national zakat potential, the collection of zakat funds in LAZ DD in 2016 decreased from the previous year's acquisition. It is recorded that the acquisition of LAZ DD reached $-5.2 \%$, while in the same year the growth of national zakat reached $37.34 \%$. In general, the growth of LAZ DD zakat management from 2012 to 2016 was still below the national growth average. The average growth of LAZ DD acquisition was $3.45 \%$, while the national growth average was $23.1 \%$. This value was still far from the annual growth target set by LAZ DD, which was $30 \%$

In Table 2, it can be seen that the collection of zakat funds from LAZ DD for the period of 2012-2016 experienced ups and downs each year and had not been able to exceed the growth rate of national zakat. The percentage of managed zakat growth by LAZ DD was still below the percentage growth of national zakat.
Muzakki activities that directly pay zakat to mustahik or through informal procedures are also reasonable because this is driven by the motivation of muzakki to pay zakat to informal institutions. Kasri (2013) found that the credibility of official institutions in terms of marketing and management is lacking. There is also the reason muzakki does not pay to zakat institutions as figured out by Siregar (2016) in his research on the problem of fundrasing. Siregar (2016) discovered that laws and regulations of zakat have not been implemented effectively, there are no professional human resources, administrative and financial systems that are still weak so they cannot carry out transparency and publication. As for the importance of zakat administration and in line with Siregar (2016), Yasmin et al. (2013) and Adamu et al. (2016) stated the importance of administration in zakat and alms, but there is still enough space for LAZ DD to optimize the growth of its managed zakat because donors who have a high level of trust in institutions tend not to think of report problems as found in Yasmin et al. (2013).

Meanwhile, if it is associated with data on the employee performance assessment of the Fundraising Division of LAZ DD in 2016, only a few employees got an A in their performance evaluation. Performance Assessment Data from Human Capital Dompet Dhuafa shows that the number of employees who got an assessment in category A was only 15 people or only $15.3 \%$, while those who got an assessment in category $\mathrm{C}$ were 32 people or $32.65 \%$ and the most were category B with 51 people or $52 \%$. The employee performance assessment of the fundraising division shows that employee performance was still not optimal and can still be optimized.

According to Mathis and Jackson (2011) there are 3 main factors that influence employee performance, these factors are: (1) the individual's ability to do the job, (2) the level of effort devoted, and (3) the organizational support. Several previous studies such as Damayanthy (2013) and Irawan (2016) used this theory to measure employee performance. This research also used the basis of Mathis and Jackson's theory with the development of aspects of organizational support. The development that is carried out is to see the organizational support as a whole, both vertically (management), horizontally (internal division), and program division support. The support of these three aspects is the renewal of this research. Several studies also mentioned the factors that influence performance significantly, those are: Employee Engagement (Wiseto 2016); Compensation, Leadership 
Style and Work Environment (Mandey and Lengkong, 2015; Syafei, 2016; Basri et al.2017).

The purpose of this study are: to analyze the employee performance of Fundraising Division of LAZ DD according to the attitude of respondents; analyze the factors that influence the employee performance of Fundraising Division of LAZ DD and compare them with other institutions; and formulating the strategies of LAZ DD to improve the performance of the Fundraising Division. This research focuses on the analysis of the factors that influence the employee performance of the Fundraising Division of the Dompet Dhuafa Amil Zakat Institution namely the ability, effort, management support, internal division support, and program division support.

\section{METHODS}

The research approach was carried out through a survey method by distributing questionnaires conducted at LAZ DD, South Jakarta. Interviews were also conducted with the General Manager of the Fundraising Division to strengthen the results obtained. The time of research was conducted from February to November 2018.
The research population is LAZ DD fundraising division with the total of 98 people. The determination of sample size is done by using Cohen's (1992) approach in Haryono (2017) which considers statistical power and effect size. With the largest arrow that affects one construct is 5 , for significance of $0.05(5 \%)$ and minimum R2 of 0.50 , the minimum sample size that must be taken is 45 people. Taking into account these minimum conditions, this research took a total sample of 50 people. The sampling technique is purposive sampling method. The use of this method is based on the intention of representing each position level in the Fundraising division from the General Manager level to the staff level.

Likert Scale is used to measure variables or constructs based on the subjects to express their agreement, this method is known as summated scale or a scale that is summed (Ghozali, 2011). According to Sekaran (2011) the Likert Scale is designed to examine how strongly subjects agree or disagree with statements on a 5-point scale. In this research, the respondents gave their assessment on a number that fits their experience by the criteria score $1=$ Very Bad, 2 = Not Good, $3=$ Fairly Good, 4 = Good, and 5 = Very Good.

Table 1, Amount of zakat acquisition compared to zakat potential

\begin{tabular}{ccccc}
\hline Year & $\begin{array}{c}\text { Zakat acqusition } \\
\text { (billion IDR) }\end{array}$ & $\begin{array}{c}\text { Zakat Potential } \\
\text { (billion IDR) }\end{array}$ & $\begin{array}{c}\text { Comparison of zakat acqusition } \\
\text { with zakat potential (\%) }\end{array}$ & Researcher \\
\hline 2004 & 150,09 & 6,132 & 2.44 & PIRAC \\
2009 & 1,200 & 12,700 & 9.44 & PEBS FEUI \\
2010 & 1,500 & 19,000 & 7.89 & UIN Syarif Hidayatullah \\
2011 & 1,729 & 217,000 & 0.79 & Firdaus \\
2015 & 3,700 & 286,000 & 1.3 & Baznas \\
\hline
\end{tabular}

Source: puskasbaznas (2018)

Table 2. National growth of zakat collection in 2012-2016 at each OPZ (in billion)

\begin{tabular}{ccccc}
\hline Year & $\begin{array}{c}\text { LAZ DD collection } \\
\text { (billion IDR) }\end{array}$ & LAZ DD Growth (\%) & $\begin{array}{c}\text { Total growth of national zakat } \\
\text { (billion IDR) }\end{array}$ & National growth \\
\hline 2012 & 217.89 & - & $2,212.40$ & - \\
2013 & 243.59 & 11.8 & $2,639.60$ & 19.31 \\
2014 & 252.02 & 3.5 & $3,300.00$ & 25.02 \\
2015 & 272.23 & 8.0 & $3,653.27$ & 10.71 \\
2016 & 258.11 & -5.2 & $5,017.29$ & 37.34 \\
\hline
\end{tabular}

Source: puskasbaznas (2018) 
Descriptive statistical analysis is used to interpret existing data easily as stated by Saefuddin et al. (2009) that the data description is an attempt to display data so that the data can be presented properly and interpreted easily. This is strengthen by Setiawan et al. (2017) who said that descriptive statistical methods discuss the collection, summarizing, measuring, centralizing, distributing data in order to be able to present data into a useful and more understood information. The assessment of this analysis by looking at the median of the measures used to measure the attitude of respondents using a Likert Scale. The median value is used in analyzing this research data because by looking at the median, the distribution of data values can be well known. In the descriptive analysis of this research, the value of 1 (one) for the median means "Very Poor" (STB), the value of 2 (two) means "Not Good" (TB), the value of 3 (three) means "Good enough" (CB), the value of 4 (four) means "Good" (B), and the value of 5 (five) means "Very Good" (SB).

This research used Partial Least Squares Structural Equation Modeling (PLS-SEM) because it has many advantages such as performing abnormal data analysis, small sample size (Hair et al. 2012), (Hair-jr et al. 2014). Besides, PLS is a useful tool in exploitative research (Nitzl et al. 2016), and is often used as the first stage in the development of theory (Richter et al. 2014). The thing that needs to be considered in using PLS is that the GOF index is not suitable for validating the model (Hanseler and Sarstedt, 2012).

In general, PLS-SEM aims to test predictive relationships between constructs by looking at whether there is a relationship or influence between the constructs. The logical consequence of using PLS-SEM is that testing can be done without a strong theoretical basis, ignoring some assumptions (non-parametric) and the accuracy parameters of the prediction model seen from the coefficient of determination (R2). PLS-SEM is very suitable to be used in research aimed at developing theory (Haryono, 2017).

Mathis and Jackson (2011) performance theory and several previous research reviews are the basis of the operational framework of variables in this research. There are 6 variables to be examined, namely: ability, effort, internal support of Fundraising Division, management support, program division support and employee performance. Employee performance factor is dependent variable, while others are independent variables.
The effort factor is reflected by motivation, work ethics, attendance, and assignment design. The ability factor is reflected by skills, interests, knowledge, educational background, and work experience. The internal support factor of the fundraising division is reflected by tools and technology, performance standards, coworkers, leadership, and work environment. The management support factor is reflected by training and development, management, and reward systems. The factor of program division support is reflected by the performance of the program division as well as reports and empowerment socialization. While the employee performance factor is reflected by the quality of work, punctuality, initiative, capability, and communication.

Based on the background, research problems, research objectives, literature review, and the theoretical framework that has been formulated above, this research determines five temporary answers (hypotheses), as follows:

H1a : The Capability Factor significantly influences the employee performance of Fundraising Division of LAZ DD

$\mathrm{H} 1 \mathrm{~b}$ : Effort Factor significantly influences the employee performance of Fundraising Division of LAZ DD

H1c : Internal Support Factor of the Fundraising Division significantly influences the the employee performance of Fundraising Division of LAZ DD

H1d : Management Support Factor significantly influences the the employee performance of Fundraising Division of LAZ DD

H1e : Program Division Support Factor significantly influences the the employee performance of Fundraising Division of LAZ DD

\section{RESULTS}

\section{Employee Performance Analysis}

Based on the respondent's assessment, the respondents' performance is generally considered good, this can be seen from the median score of 4 with a good category (B). This can be seen from the attitude of the respondents regarding the Quality of Work, Initiative and Communication which is considered good. This performance score with a good category is in accordance with performance assessment data carried out by HRD 
DD. One thing that attracts attention is in one indicator of timeliness, that is, planned activities have a low median value, which is 2 with a bad category (TB). Attitudes of respondents to their performance in Table 3.

\section{Factors Affecting Employee Performance}

In the SEM-PLS method, the initial step is to test the validity of the measurement model (outer model) by testing convergent validity, discriminant validity and reliability analysis. Convergent validity of the

Table 3. Attitudes of respondents to their performance

\begin{tabular}{lc}
\hline Performance & Median \\
\hline WORK QUALITY & 4 \\
Achievement of the Target & 4 \\
Compliance with Procedures & 4 \\
Result Quality & \\
PUNCTUALITY & 4 \\
On Time & 2 \\
Planned Activity & 4 \\
Achievement of Each Phase & \\
\hline
\end{tabular}

measurement model with reflexive indicators can be seen from the correlation between item/indicator scores and the construct score. Individual indicator is considered reliable if it has a correlation value above 0.70. However, in the scale development research level, loading 0.50 to 0.60 is still acceptable by looking at the output of the correlation between the indicator and the construct (Ghozali, 2011). The results of processing data show all loading factors $>0.5$ and are in the range of $0.502-0.848$. The complete results can be seen in Table 4.

\begin{tabular}{lc}
\hline Performance & Median \\
\hline INITIATIVE & 4 \\
Steps Preparation & 4 \\
Problem Solving & \\
ABILITY & 4 \\
Carrying Out Work Well & 4 \\
Compliance with Job Descriptions & \\
COMMUNICATION & 5 \\
Communication with coworkers & 4 \\
Communication with supervisors & 4 \\
Ease in communication & \\
\hline
\end{tabular}

Table 4. Outer Loading test results that have Loading above 0.5

\begin{tabular}{|c|c|c|c|c|c|}
\hline No & & Original sample & No. & & Original sample \\
\hline 1 & DP1 $\leftarrow$ Division Support & 0.785 & 17 & PD2 $\leftarrow$ Capability & 0.694 \\
\hline 2 & DP2 $\leftarrow$ Division Support & 0.751 & 18 & PK1 $\leftarrow$ Capability & 0.674 \\
\hline 3 & DP3 $\leftarrow$ Division Support & 0.848 & 19 & PK2 $\leftarrow$ Capability & 0.769 \\
\hline 4 & DP4 $\leftarrow$ Division Support & 0.812 & 20 & PG1 $\leftarrow$ Capability & 0.659 \\
\hline 5 & LS1 $\leftarrow$ Division Support & 0.757 & 21 & PG3 $\leftarrow$ Capability & 0.502 \\
\hline 6 & $\mathrm{KP} 1 \leftarrow$ Performance & 0.778 & 22 & MN1 $\leftarrow$ Capability & 0.508 \\
\hline 7 & KK1 $\leftarrow$ Performance & 0.690 & 23 & KT1 $\leftarrow$ Capability & 0.778 \\
\hline 8 & KK2 $\leftarrow$ Performance & 0.773 & 24 & KT3 $\leftarrow$ Capability & 0.611 \\
\hline 9 & KM1 $\leftarrow$ Performance & 0.777 & 25 & MJ2 $\leftarrow$ Management Support & 0.757 \\
\hline 10 & KW3 $\leftarrow$ Performance & 0.819 & 26 & PP1 $\leftarrow$ Management Support & 0.719 \\
\hline 11 & EK1 $\leftarrow$ Effort & 0.579 & 27 & $\mathrm{PP} 2 \leftarrow$ Management Support & 0.729 \\
\hline 12 & EK3 $\leftarrow$ Effort & 0.835 & 28 & PP4 $\leftarrow$ Management Support & 0.831 \\
\hline 13 & MT2 $\leftarrow$ Effort & 0.589 & 29 & PM $2 \leftarrow$ Internal Support & 0.741 \\
\hline 14 & MT3 $\leftarrow$ Effort & 0.673 & 30 & TK1 $\leftarrow$ Internal Support & 0.678 \\
\hline 15 & RT1 $\leftarrow$ Effort & 0.742 & 31 & TK2 $\leftarrow$ Internal Support & 0.757 \\
\hline \multirow[t]{2}{*}{16} & RT2 $\leftarrow$ Effort & 0.662 & 32 & SK1 $\leftarrow$ Internal Support & 0.683 \\
\hline & & & 33 & RK3 $\leftarrow$ Internal Support & 0.767 \\
\hline
\end{tabular}


The discriminant validity of the reflexive indicator can be seen from the cross loading between the indicator and the construct. Indicators whose correlation values are greater in the construct indicate that latent constructs predict indicators on their blocks better than other block of indicators (Ghozali, 2011). The results show the value of cross loading on the variable is greater than the correlation with other variables and the value is $>$ 0.5 . This shows the indicator on that variable reflects the latent variable. The complete results can be seen in Table 5.

This reliability analysis aims to prove the accuracy, consistency and accuracy of the instrument in measuring the construct. This analysis can be done in two ways, namely Alpha Cronbach and Composite Reliability, where both values must be greater than 0.60 . Table 6 shows the results of the reliability test on the model.

After doing the evaluation of the measurement model, the next step is to test the structural model. There are several criteria in evaluating structural models, namely the coefficient of determination (R-square), and the value of the path coefficient itself (Surienty et al. 2013). $\mathrm{R}$-square and path analysis indicate how well the data supports the proposed hypothesis. R-square is also used to see the extent to which exogenous variables are able to explain the diversity of the dependent variables. The value of $\mathrm{R}$-squares of 0.75 concludes that the model is strong, 0.50 as a moderate model, and 0.25 as a weak model (Latan and Ghozali, 2012). As can be seen from Figure 1, the R-square in this research is 0.690 which can be interpreted as a moderate model.

As for the other factors that affect Performance and the Zero Hypothesis (H0) that are rejected are the Program Division Support Factors which have t-statistics above $\mathrm{t}$ count $(3.768>1.65)$ and $\mathrm{p}$ values below $0.1(0.000$ $<0.1)$ so $\mathrm{H0}$ is rejected or the Factor of Program Division support significantly affects the employee performance of Fundraising division. The second factor that influences Performance is the Internal Support Factor of the Fundraising Division which has $\mathrm{t}$-statistics above $\mathrm{t}$ count $(1.784>1.65)$ and $\mathrm{p}$ value below $0.1(0.075<0.1)$ so $\mathrm{H} 0$ is rejected or the Internal Support Factor of the Fundraising Division significantly influences the employee performance of the Fundraising Division. The third factor that influences Performance is the Effort Factor which has t-statistics above $\mathrm{t}$ count $(2.191>1.65)$ and $p$ value below $0.1(0.029<0.1)$ so $\mathrm{HO}$ is rejected or Effort Factors significantly affect employee performance of Fundraising division. Then from the three factors that have a significant effect has a positive effect (positive path coefficient), which means that if the Program Division Support, Internal Support of Fundraising Division and Effort factors increase, the performance will also improve. As shown in Table 7.

Table 5. Discriminant validity test

\begin{tabular}{lcccccc}
\hline \multicolumn{1}{c}{ Indicator } & $\begin{array}{c}\text { Program div. } \\
\text { support }\end{array}$ & $\begin{array}{c}\text { Internal div. } \\
\text { support }\end{array}$ & $\begin{array}{c}\text { Management } \\
\text { support }\end{array}$ & $\begin{array}{c}\text { Capability } \\
\text { factor }\end{array}$ & Effort factor & Performance \\
\hline Program div. support & $0.691-0.785$ & $0.155-0.389$ & $0.290-0.398$ & $0.291-0.468$ & $0.346-0.571$ & $0.391-0.612$ \\
Internal div. support & $-0.002-0.227$ & $0.678-0.767$ & $0.102-0.341$ & $0.158-0.520$ & $0.415-0.676$ & $0.324-0.693$ \\
Management support & $0.312-0.438$ & $0.099-0.418$ & $0.719-0.831$ & $0.426-0.739$ & $0.145-0.586$ & $0.180-0.504$ \\
Capability factor & $0.164-0.377$ & $0.028-0.513$ & $0.404-0.539$ & $0.502-0.769$ & $0.130-0.608$ & $0.021-0.469$ \\
Effort factor & $0.266-0.530$ & $0.244-0.651$ & $0.259-0.560$ & $0.281-0.531$ & $0.579-0.835$ & $0.325-0.632$ \\
Performance & $0.308-0.600$ & $0.284-0.614$ & $0.268-0.416$ & $0.233-0.462$ & $0.380-0.656$ & $0.594-0.819$ \\
\hline
\end{tabular}

Table 6. Reliability test results

\begin{tabular}{lcc}
\hline Construck & Alpha Cronbach & Composite Reliability \\
\hline Program division support & 0,839 & 0,885 \\
Internal division support & 0,785 & 0,847 \\
Management support & 0,798 & 0,845 \\
Capability & 0,849 & 0,856 \\
Effort & 0,783 & 0,853 \\
Performance & 0,774 & 0,840 \\
\hline
\end{tabular}




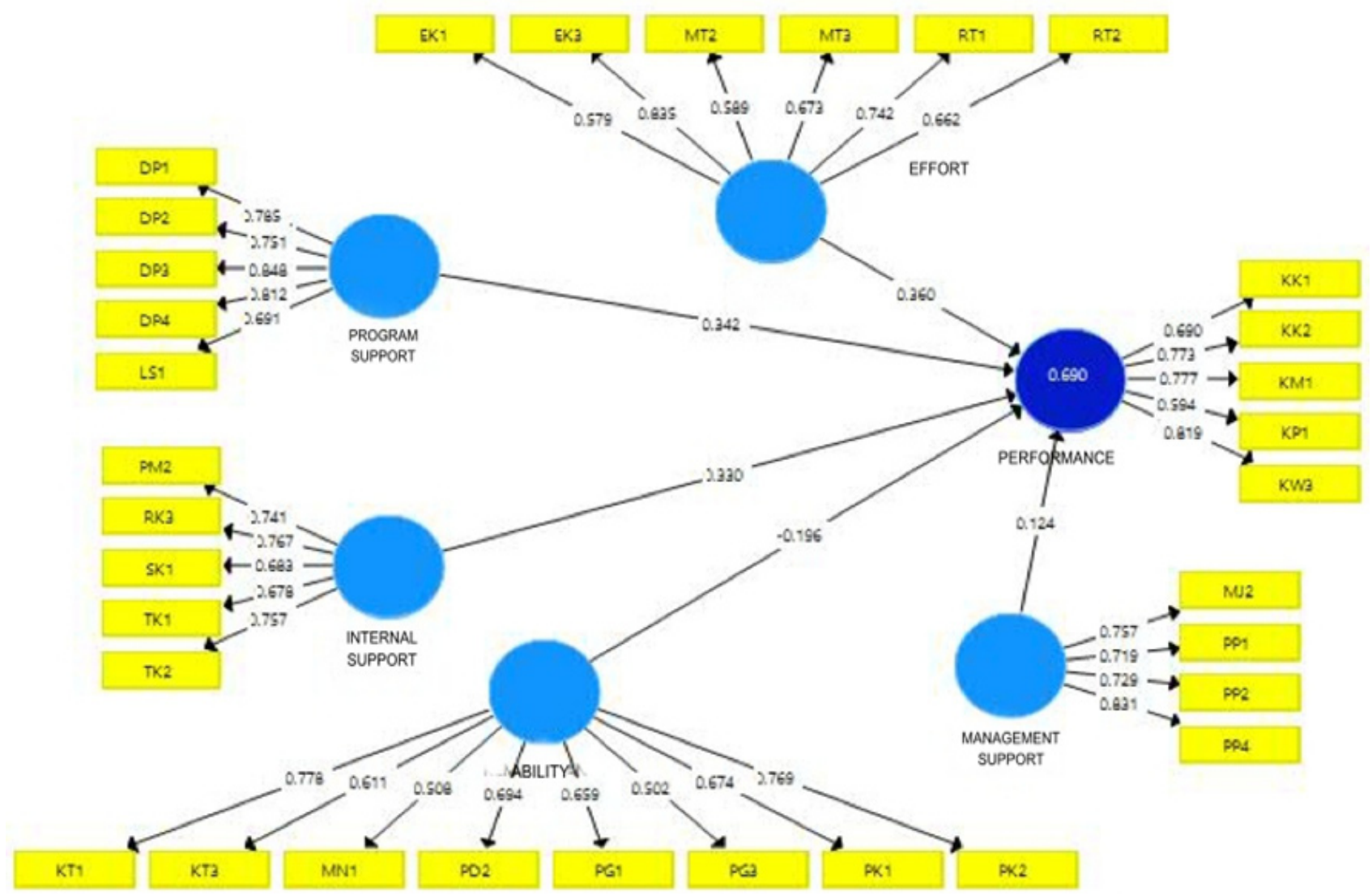

Figure 1. Partial least squares estimation with loading above 0.5

Table 7. Value of path coefficient and R-square

\begin{tabular}{lccccc}
\hline Correlation & Path coefficient & Statistik t & p-value & R-square & Decision \\
\hline Program division support $\rightarrow$ Performance & 0.342 & 3.768 & 0.000 & & H0 rejected \\
Internal support of fundraising division $\rightarrow$ Performance & 0.330 & 1.784 & 0,075 & & H0 rejected \\
Management support $\rightarrow$ Performance & 0.124 & 0.806 & 0.421 & 0.690 & H0 accepted \\
Capability $\rightarrow$ Performance & -0.196 & 0.198 & 0.364 & & H0 accepted \\
Effort $\rightarrow$ Performance & 0.360 & 2.191 & 0.029 & H0 rejected \\
\hline
\end{tabular}

The three factors that affect the Fundraising employee performance in detail have indicators that have a large loading factor, among others are:

1. Factors of Program Division Support: Program Performance (increasing number of Zakat recipients, widespread distribution area, program that attracts muzakki/donor, success in poverty alleviation programs), Empowerment Report and Socialization.

2. Internal Support of the Fundrasing Division: equipment and technology (required and in good conditions), Performance Standards, Colleagues, and Leadership

3. Effort Factors: Motivation (attendance and target achievement), Work Ethics (professional attitude), and Draft Tasks (make plans and targets achieved)
The factors that have the greatest influence sequentially seen from the path coefficient are Efforts factor, Program Division Support and Internal Support of Fundraising Division. Effort factors have the biggest influence on performance because it is related to the employee motivation of Fundraising division. Motivation is significant in improving performance because the motivation that comes within the employees becomes an encouragement to work better, as found by Iqbal et al. (2013) that motivation as a moderator positively influences the relationship between employee performance and performance assessment. The professionalism attitudes of employees in working shows the sincerity of employees in working or show totality in work. Likewise, the Draft Tasks which is made by the employees in achieving targets are also one of the proofs in showing the totality in working. 
The second influential factor is the support of the program division. The form of program division support is in terms of program performance and reports as well as socialization. Muzakki or donors will see how well the program performance and reports. Agood program performance will encourage and influence muzakki in the fundraising process (Abidah, 2016). The third influential factor is the internal support of the Fundraising division, one of which is related to leadership in the Fundraising division. This is in accordance with the findings of Renard and Snelgar (2016) that the employee performance of non-profit organizations must be encouraged by their managers to achieve the highest level of desire of the employees, including the level of the organization. Empowering the non-profit employees can be achieved by ensuring that they know and understand the vision, mission, values, culture, objectives and business model of the organization and facilitate independent development.

As for the factors that influence performance in other institutions are reflected in the following studies, among others are: Mandey et al. (2015) in his research found that Compensation, Leadership Style and Work Environment have a simultaneous effect. In line with the study of Mandey et al. (2015), Syafei (2016) in his research revealed that Organizational Culture, Motivation, Leadership had an influence on the performance and the highest influence was the Leadership factor. Basri et al. (2017) also stated that employee performance is influenced by leadership style. Leadership and motivation factors in other institutions have similarities in terms of influence on performance, however compensation factors and work environment in Fundrasing division of LZ DD have no influence on performance because employees know that LAZ DD is a social-religious institution so they don't think about compensation and work environment.

A similar thing also found by Zhu et al. (2016) that the support of Boards of Director (BoD)/ Directors is significant in shaping employee performance to be better. Moreover, the involvement of the Board of Directors in determining the formation of organizational strategy will trigger innovation and employee performance. The same thing was revealed by Setyaningrum et al. (2017), that is organizational commitment and trust affect employee performance. However, this is different from the findings in LAZ DD, in the Fundraising division, the Management support did not have a significant effect in improving Fundraising employee performance because it did not come into direct contact with employees in the field.

The interesting part in improving performance is the company's efforts to create programs that involve employees in activities related to Corporate Social Responsibility (CSR). A study by Knox (2018) states that programs run by companies specifically related to aspects of CSR affect the employee performance of the company. As it is known that the activities and programs in LAZ DD are all social so LAZ DD employees are expected to have good performance because of their work motivation in the social field.

\section{Strategy for Improving Employee Performance}

Based on Figure 2, there are various recommendations of managerial strategy that can be given to DD management in an effort to improve the employee performance of Fundraising division. This recommendation only focuses on the High Priority quadrant and on the area above the diagonal $\left(45^{\circ}\right)$, because the indicators in the area have a big influence on employee performance in the fundraising division and low attitude values. In this area there are 5 (five) indicators, namely PM2, EK3, DP1, DP3, and DP4. In detail PM2 is one of the leadership indicators that looks at the respondents' attitude to leaders who have longterm plans and can explain the plan to his subordinates. EK3 is one indicator of Work Ethics that looks at the of respondents' professionalism in working. DP1 is one of the indicators of Program Performance that look at the respondents' attitudes to the increasing number of Zakat recipients (mustahik) each year. DP3 is one of the program performance indicators who looks at respondents' attitudes to the interesting programs. Then DP4 is one of the Program Performance indicators that look at the respondents' attitude of to the increase number of mustahik who become muzakki.

As for the recommendations that can be made by the Dompet Dhuafa management to improve the employee performance of the Fundrasing division are:

\section{Making Leadership Training for leaders}

At the moment the supervisor is still lacking in terms of long-term planning and can not deliver planning to his subordinates, this will cause problems on the communication of important matters such as fundraising strategies which is needed to achieve the targets set by 
the institution. In addition to the training on making strategic planning, leaders also need to be equipped with a good leadership methods. Moreover, training interventions still have a positive and strong impact in improving employee performance (Budiningsih et al. 2017).

\section{Internalize the values of Dompet Dhuafa}

Dompet Dhuafa (DD) has values that are adopted, among others are: Islamic, Universal, Caring, Innovative, Responsive, Trustful, and Professional. The seven values adopted by DD are abbreviated as INSPIRASI. The internalization of DD values is expected to increase the professionalism of employees and maintain teamwork. Internalization of values can be done by training, thematic studies, putting up pictures on the wall, making easy and memorable march, and etc. Institutional values are important for improving employee performance as found by Tang et al. (2016) who carried out a case study on supervisor level workers in China and Taiwan, Tang et al. (2016) revealed that organizational value became a mediating variable on employee performance. The higher the value of the organization, the more positive the employee performance will be.

3. Maintain and improve the Performance of the LAZ DD Program Division

in order to provide factual evidence of the benefits of zakat to the community and have an impact on public awareness to give charity to the poor or giving Zakat at formal institutions such as LAZ DD, as found by Anwar (2012). Nowadays, the performance of DD program division is good, maintaining and improving the performance of the division of the program will help the employee of Fundraising Division to achieve the targets set. As for the performance of the program division in question is: increasing the number of Zakat recipients, increasing the distribution of the benefits, making programs that attract muzakki/donors, and increasing the number of mustahik that become muzakki.

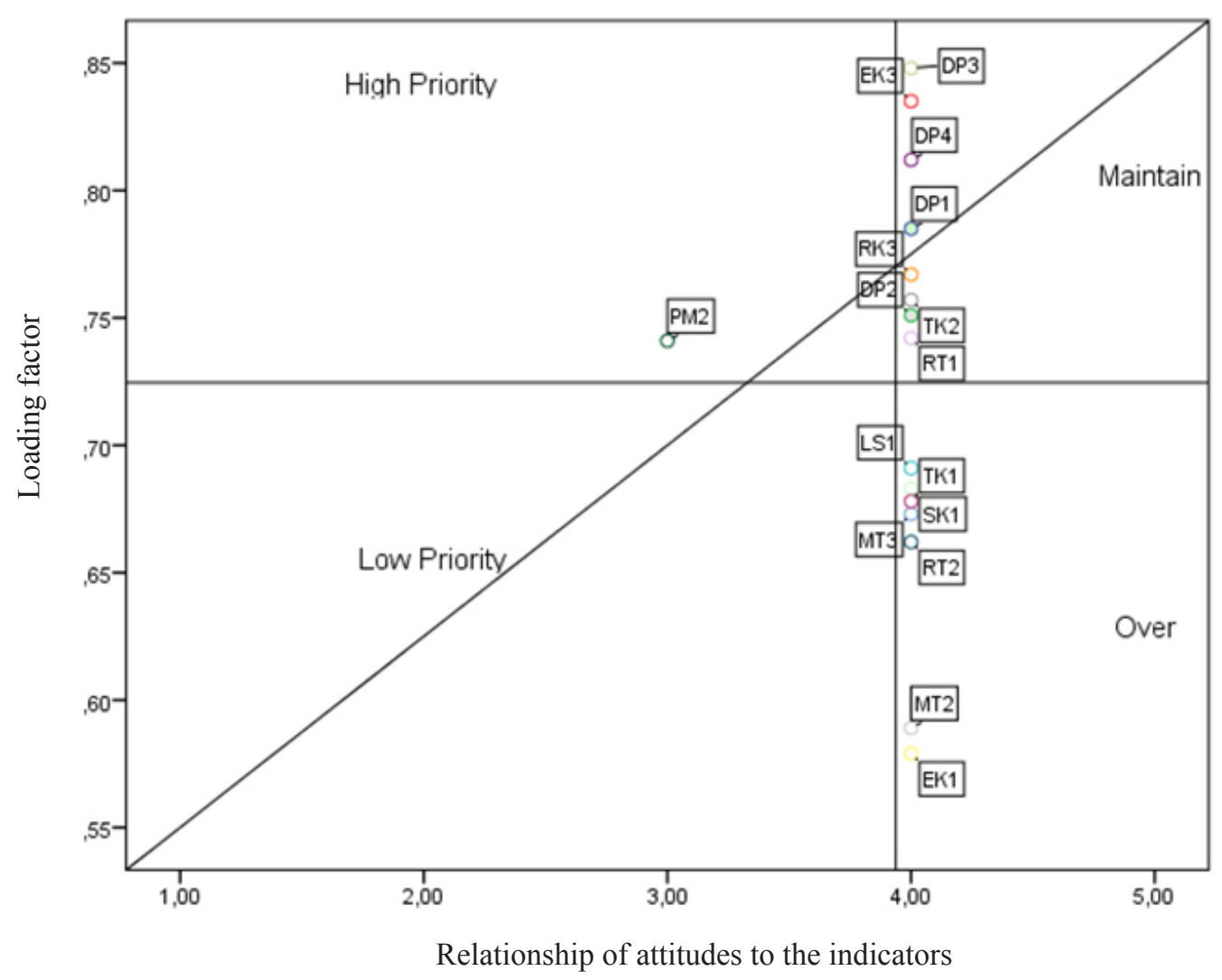

Figure 2. Relationship of Attitudes to the Indicators with Loading Factor 


\section{Managerial Implications}

Several important things that can be done by management of Dompet Dhuafa to help improving the employee performance of Fundraising division are as follows: 1) Internalization efforts starting from the level Board of Directors in the form of direction at each meeting, becoming role models in everyday life and policies decided, all cannot be separated from the value of Dompet Dhuafa; 2) The Human Capital Division evaluates employees (assessment) related to leadership that is needed to improve employee performance and then carry out leadership training for managerial levels; 3) Appreciation for the achievement of employee performance both in the Fundraising and Program division is done by the management of DD in the form of policies so the employees are motivated to improve their performance.

\section{CONCLUSIONS AND RECOMMENDATIONS}

\section{Conclusions}

Based on the results of the research analysis that has been conducted, it can be concluded several things, among others: The respondents' attitude related to employee performance is categorized as Good. As for the factors that influence the performance of the Fundraising division are: Internal Support of the Fundraising Division, Effort Factors, and Program Division Support. Furthermore, the relationship between the three of them to performance is positive. The factors that have the greatest influence sequentially seen from the path coefficient are Efforts, Program Division Support and Internal Support of Fundraising Division. Subsequently, the strategy of LAZ DD to improve the employee performance of Fundraising division is by making leadership training for leaders, time management training for employees, internalizing the values of DD, and providing device and technology to work in good conditions, as well as maintaining and improving the performance of Program division.

\section{Recommendations}

Some suggestions that can be given based on the results of this study are as follows: The management of DD must focus more on improving leadership capacity because the research results prove that leadership indicators have a large loading factors and value of attitudes toward indicators is low. A large loading factor indicate the significance of indicators in affecting the employee performance of Fundraising division. This research is limited to the study of the employee performance of the fundraising division at LAZ DD only. It is suggested for future researcher to conduct a study about the performance of Fundraising division in other institutions in order to be more sure of what factors that can influence the zakat institution in improving the performance of its employees. Efforts to improve the employee performance of the Fundraising division need to be examine from the other side of management to find the right formula in improving the performance of the Fundraising division in more comprehensive way.

\section{REFERENCES}

Abidah A. 2016. Analisis strategi fundraising terhadap peningkatan pengelolaan ZIS pada lembaga amil zakat kabupaten ponorogo. Kodifikasia 10(1):163-189.

Adamu, Ummulkhayr, Owoyemi MY, Cusairi RM. 2016. Zakah administration and its importance: A review. IOSR Journal of Humanities And Social Science (IOSR-JHSS) 21(8):115-120.

Anwar ASH. 2012. Model tatakelola badan dan lembaga amil zakat sebagai upaya untuk meningkatkan pemberdayaan ekonomi masyarakat (studi pada badan/lembaga amil zakat di kota malang). Jurnal Humanity 7(2): 1-13.

Basri HH, Rashid IMA, Abashah AB, Samah IHA. 2017. The Roles of Transformational Leadership Style form Maintaining Employee in Team Performance; Empirical Study in Malaysia's Pharmacy Industry. International Journal of Information, Business and Management 9(2): 37-44.

[BAZNAS] Badan Amil Zakat Nasional. 2017. Outlook Zakat Indonesia 2017. Jakarta: Pusat Kajian Strategis Badan Amil Zakat Nasional.

Budiningsih I, Dinarjo Tj, Ashari Z. 2017. Improvement of employee's performance through training intervention in digital era. European Research Studies Journal 20(4): 637-654.

Canggih C, Fikriyah K, Yasin A. 2017. Potensi dan realisasi dana zakat di Indonesia. Al-Uqud: Journal of Islamic Economics 1(1): 14-26. https:// doi.org/10.26740/al-uqud.v1n1.p14-26.

Damayanthy D. 2013. Analisis faktor-faktor yang mempengaruhi kinerja pegawai di perusahaan 
daerah pasar Tohaga Kabupaten Bogor [thesis]. Bogor: Sekolah pascasarjana, IPB.

Ghozali I. 2011. Model Persamaan Struktural Konsep dan Aplikasi dengan Program AMOS 19.0. Semarang: Badan Penerbit-Undip

Hair JF, Sarstedt M, Ringle CM, Mena JA. 2011. An assessment of the use of partial least squares structural equation modelling in marketing reasearch. Journal of the Academy of Marketing Science 40(3):414-433. https://doi.org/10.1007/ s11747-011-0261-6.

Hair-jr JF, Sarstedt M, Hopkins L, Kuppelweiser VG. 2014. Partial least squares structural equation modeling (PLS-SEM). European Business Review 26(2):106-121. https://doi.org/10.1108/ EBR-10-2013-0128.

Hanseler J, Sarstedt M. 2012 Goodness of fit indices for partial Least Squares path Modelling. Comput Stat 28(3):565-580. https://doi.org/10.1007/ s00180-012-0317-1.

Haryono S. 2017. Metode SEM untuk Penelitian Manajemen dengan AMOS LISREL PLS. Jakarta: Luxima Metro Media.

Irawan A. 2016. Analisis faktor-faktor yang memengaruhi kinerja pegawan negeri sipil di Direktorat Jenderal Pendidikan Tinggi [tesis]. Bogor: Institut Pertanian Bogor.

Iqbal N, Ahmad N, Haider Z, Batool Y, Qurat-ulain. 2013. Impact of performance appraisal on employess's performance involving the moderator role of motivation. Arabian Journal of Business and Management Review (OMAN Chapter) 3(2): 37-56. https://doi. org/10.12816/0002354.

Kasri RA. 2013. Giving behaviors in Indonesia: motives and marketing implications for Islamic charities. Journal of Islamic Marketing 4(3):306-324. https://doi.org/10.1108/JIMA-05-2011-0044.

Knox BD. 2018. Employee volunteer programs are associated with firm-level benefits and CEO incentives: data on the ethical dilemma of corporate social responsibility activities. Journal of Business Ethics 2018: 1-24. https://doi. org/10.1007/s10551-018-4005-0.

Latan H, Ghozali I. 2012. Partial Least Quares: Konsep, Teknik dan Aplikasi Menggunakan Program Smart PLS 2.0 M3. Semarang: Badan Penerbit Universitas Diponegoro.

Mandey MA, Lengkong VPK. 2015. Pengaruh kompensasi, gaya kepemimpinan, dan lingkungan kerja terhadap kinerja pegawai. Jurnal EMBA 3(3):1383-1394.

Mathis RL, Jackson JH. 2011. Manajemen Sumber Daya Manusia. Ed ke-10. Jakarta: Salemba Empat.

Renard M, Snelgar RJ. 2016. How can work be designed to be intrinsically rewarding? qualitative insights from South African non-profit employees. $S A$ Journal of Industrial Psychology 42(1):1-12. https://doi.org/10.4102/sajip.v42i1.1346.

Richter NF, Sinkovics RR, Ringle CM, Schlägel C. 2014. A critical look at the use of SEM in international business reseacrh. Internatioal Marketing Review 33(3):376-404. https://doi. org/10.1108/IMR-04-2014-0148.

Saefuddin A, Notodiputro KA, Alamudi A, Sadik K. 2009. Statistika Dasar. Jakarta: PT. Grasindo.

Setiawan A, Mahadianto MY, Solahudin A, Fatimah SE. 2017. Pengantar Statistik I. Bogor: IPB Press.

Sekaran U. 2011. Metodologi Penelitian untuk Bisnis. Jakarta: Salemba Empat.

Setyaningrum RP, Setiawan M, Surachman S, Irawanto DW. 2017. Employees performance; leadership, organizational commitment and trust. International Journal of Economic Perspectives. 11(2):281-288.

Siregar S. 2016. Problematika fundraising zakat: studi kasus baznas di Sumatera Utara. MIQOT 40(2):247-266. https://doi.org/10.30821/miqot. v40i2.299.

Surienty L, Ramayuli T, Lo MC, Tarmizi AN. 2013. Quality of work life and turn-over intention: a partial least square (PLS) approach. Social Indicators Research 119(2014):405-420. https:// doi.org/10.1007/s11205-013-0486-5.

Syafei M. 2016. Pengaruh budaya organisasi, motivasi, kepemimpinan, dan lingkungan kerja terhadap kinerja karyawan PT. PUL Logistics Indonesia[tesis]. Bogor: Institut Pertanian Bogor or.

Tang J, Liu M, Liu W. 2017. How workplace fun influences employees' performance: the role of person-organization value congruence. Social Behavior and Personality 45(11):1787-1802. https://doi.org/10.2224/sbp.6240.

Wiseto A. 2016. Pengaruh employee enggagement terhadap peningkatan kinerja grup retail risk PT. Bank Mandiri tbk[tesis]. Bogor: Institut Pertanian Bogor. 
Yasmin S, Haniffa R, Hudaib M. 2013. Communicated accountability by faith-based charity organisations. Journal of Business Ethics 122(1):103-123.https://doi.org/10.1007/ s10551-013-1759-2.
Zhu H, Wang P, Bart C. 2016. Board processes, board strategic involvement, and organizational performance in for-profit and non-profit organization. Journal of Business Ethics 136(2):311-328.https://doi.org/10.1007/s10551014-2512-1. 